\title{
HUBUNGAN KECERDASAN EMOSIONAL DENGAN GAYA PEMECAHAN KONFLIK PERAWAT
}

\author{
Endah Tri Wijayanti*, Muhammad Mudzakkir \\ Jurusan DIII Keperawatan, Fakultas Ilmu Kesehatan, Universitas Nusantara PGRI Kediri \\ *endahfajarina@gmail.com
}

\begin{abstract}
Abstrak
Perawat merupakan profesi yang berhubungan dengan banyak orang yang mempunyai latar belakang berbeda. Hubungan tersebut beresiko memicu terjadinya konflik. Konflik dapat diselesaikan dengan manajemen konflik melalui pendekatan gaya manajemen konflik. Penyelesaian konflik mempunyai korelasi dengan kecerdasan emosional seseorang. Penelitian ini bertujuan untuk mengetahui level kecerdasan emosional dan pemilihan gaya manajemen konflik serta menganalisis hubungan antara kedua variabel. Penelitian ini menggunakan desain cross sectional dengan pendekatan deskriptif yang dilakukan pada 30 responden perawat pelaksana di RSM Ahmad Dahlan Kota Kediri. Adapun instrument yang digunakan adalah data demografi, kecerdasan emosional, dan pilihan gaya manajemen konflik. Hasil dari penelitian ini adalah ratarata gaya kompetisi $(M=1,2)$, kolaborasi $(M=1,93)$, menghindar $(M=2)$, kompromi $(M=2,2)$, akomodasi $(M=2,867)$; sedangkan kecerdasan emosional dengan nilai tinggi (43\%), rendah (57 $\%)$. Terdapat hubungan negative antara dimensi kesadaran diri dengan gaya kompetisi $(\mathrm{r}=$ $0,667 ; \mathrm{p}=0,00)$; dan hubungan positif antara dimensi manajemen diri dengan gaya akomodasi ( $\mathrm{r}$ $=0,473 ; \mathrm{p}=0,008)$. Terdapat hubungan antara dimensi kesadaran diri dengan gaya kompetisi, serta manajemen emosi dan gaya akomodasi. Pelatihan tentang strategi manajemen konflik dan manajemen kecerdasan emosi penting bagi perawat untuk menjaga motivasi kerja.
\end{abstract}

Kata kunci: Kecerdasan emosional, gaya pemecahan konflik perawat

\begin{abstract}
Relationships of emotional intelligence with nursing conflicts of nursing conflicts. This study analyzes the level of emotional intelligence and conflict management styles and correlation between them. This study used a cross sectional design with a descriptive approach with 30 nurses at Ahmad Dahlan Hospital in Kediri. Demography instrument, emotional intelligence, and Thomas Killman instruments (TKI) was used to collect data. The results of this study were competition style $(M=1.2)$, collaboration $(M=1.93)$, avoidance $(M=2)$, compromise $(M=$ 2.2), accommodation $(M=2.867)$; while emotional intelligence with high scores level (43\%) and low level (57\%). There was a negative correlation between self awareness and competition style $(r=-0.667 ; p=0.00)$; positive correlation in managing emotion with accommodation style $(r=$ 0,473; $p=0,008)$. There was a corelation between self awareness and competition style, also managing emotion and accomodation style. Training in skill of conflict management and emotional intelligence was important for nurses to maintain work motivation.
\end{abstract}

Keywords: Emotional intelligence, conflict management style of nurse

\section{Pendahuluan}

Keperawatan merupakan sebuah profesi yang berisiko terjadinya konflik, karena senantiasa berhubungan secara interpersonal dengan orang yang memiliki perbedaan nilai, kepercayaan, latar belakang budaya dan tujuan, yang semuanya dapat menjadi sumber konflik (Jones, 2007). Oleh karena itu pemahaman terhadap bagaimana manajemen stress dengan konflik yang terjadi menjadi hal yang penting untuk dikuasai. Stress dan konflik merupakan dua hal yang tidak dapat dipisahkan, akan tetapi bisa dilatih dengan meningkatkan skil EmotionalIntelegency (EI) untuk menguranginya (Yamani, Shahabi, \& Haghani, 2014).

Konflik dapat menyebabkan masalah secara emosional, stress dan bisa juga menyebabkan kepuasan kerja menurun(Obied \& Ahmed, 2016). Konflik dapat memicu peningkatan pergantian tenaga kerja, penurunan produktivitas kerja dan moral(Shapiro, 2014). Banyak faktor yang memberikan kontribusi dalam 
memunculkan konflik di rumah sakit meliputi kondisi kerja, jadwal kerja, dan kebijakan administratif (Omisore \& Abiodun, 2014). Ketidakcukupan pendapatan tanggung jawab administratif, beban kerja yang tinggi, serta kurangnya otonomi perawat merupakan kondisi kerja yang bisa mempengaruhi konflik.

Konflik dapat menjadi faktor yang destruktif dan konstruktif bagi diri seseorang(Yamani et al., 2014)(Rahim, 2017). Kurangnya kecerdasan emosional dapat memicu terjadinya konflik karena kecerdasan emosional berkaitan dengan sensitivitas seseorang dalam memahami orang lain (Mohamed \& Yousef, 2014). Hasil penelitian menyatakan bahwa ada korelasi positif antara kecerdasan emosional dengan gaya kolaborasi dan korelasi negatif dengan gaya akomodasi (Morrison, 2008).

\section{Metode}

Penelitian ini merupakan penelitian kuantitatif untuk mengetahui korelasi antara kecerdasan emosional dalam pemilihan gaya pemecahan konflik perawat. Peneliti menggunakan instrument kecerdasan emosional dan pemilihan gaya konflik dari Thomas Killman yang terdiri dari 30 item pertanyaan. Penelitian ini mempunyai sasaran perawat yang bekerja di rumah sakit yang berbeda dengan penelitian sebelumnya yang dilakukan pada wanita dewasa dengan status sudah menikah. Penelitian ini juga menganalisis hubungan data demografi perawat dengan komponen dalam kecerdasan emosional. Adapun sampel dari penelitian ini adalah 30 orang.

Tujuan yang ingin dicapai dalam penelitian ini adalah gambaran karakteristik perawat, level kecerdasan emosional perawat, pemilihan gaya manajemen konflik, korelasi data demografi dengan komponen kecerdasan emosional, serta korelasi gaya pemecahan konflik dengan dimensi kecerdasan emosional.

\section{Hasil}

\section{Karakteristik responden}

Karasteristik responden perawat di RSM Ahmad Dahlan tersebut meliputi umur, jenis kelamin, status pernikahan, lama bekerja, serta tingkat pendidikan terakhir. Berikut adalah gambaran distribusi berdasarkan umur dan lama bekerja:

Tabel 1.

Umur dan lama bekerja responden $(n=30)$

\begin{tabular}{|c|c|c|c|}
\hline Variabel & Mean & Std. deviasi & Min-mak \\
\hline Umur & 26,97 & 3,73 & $23-39$ \\
\hline Lama kerja & 3,39 & 3,65 & $1-17$ \\
\hline
\end{tabular}

rata umur responden perawat adalah 26,97 tahun, dengan standar deviasi 3,73 (95\% CI: ). Tampak bahwa rata-rata pekerja perawat berada dalam rentang dewasa muda dengan lama bekerja bervariasi antara 1 tahun dan terlama 17 tahun. Berdasarkan Tabel 2 tampak bahwa sebagian besar responden adalah perempuan $(76,7 \%)$ dengan status sudah menikah lebih dominan $(73,3 \%)$. Tingkat pendidikan perawat sebagian besar adalah Strata $1(66,7 \%)$

Diagram 1 tampak bahwa kecerdasan emosional dengan level rendah tinggi (43\%). Diagram 2 diatas menunjukkan bahwa dimensi sadar diri merupakan dimensi kecerdasan emosional tertinggi pada diri perawat pelaksana di RSM Ahmad Dahlan Kota Kediri sebesar $90 \%$, dimensi manajemen diri sebesar $57 \%$, dimensi motivasi diri sebesar 53\%, dimensi empati terhadap orang lain sebesar $57 \%$, dan dimensi kemampuan membina hubungan antar manusia hanya sebesar $40 \%$. Bahkan yang menarik bahwa kemampuan membina data proporsi $60 \%$. Berdasarkan hasil penelitian diperoleh data bahwa perawat pelaksana memilih gaya 
manajemen konflik kompetisi sebesar $80 \%$, gaya kolaborasi $67 \%$, gaya kompromi $73 \%$, gaya menghindar $77 \%$, gaya akomodasi sebesar $83 \%$.

Tabel 2.

Karakteristik responden $(\mathrm{n}=30)$

\begin{tabular}{llll}
\hline Jenis kelamin & Laki-laki & 7 & $23,3 \%$ \\
& Perempuan & 23 & $76,7 \%$ \\
Status pernikahan & Menikah & 22 & $73,3 \%$ \\
& Belum menikah & 8 & $26,7 \%$ \\
\multirow{3}{*}{ Tingkat pendidikan } & D3 & 2 & $6,7 \%$ \\
& S1 & 20 & $66,7 \%$ \\
& S2 & 8 & $26,7 \%$ \\
\hline
\end{tabular}

Diagram 1.

Kecerdasan emosional perawat $(n=30)$

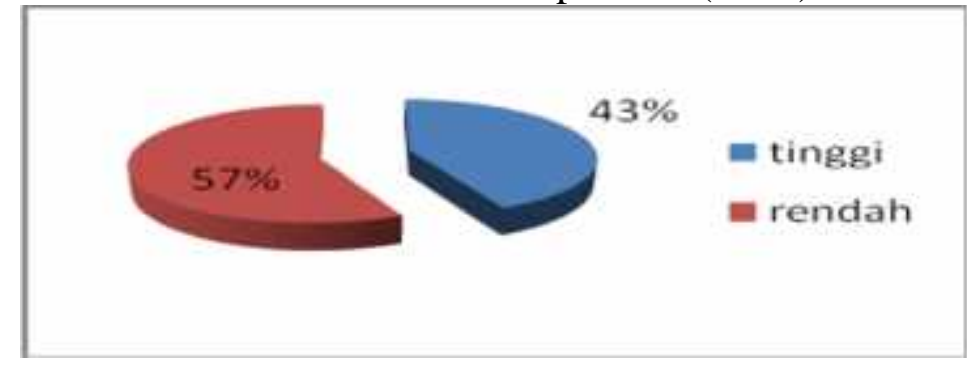

Diagram 2.

Dimensi Kecerdasan Emosional Perawat ( $\mathrm{n}=30$ )

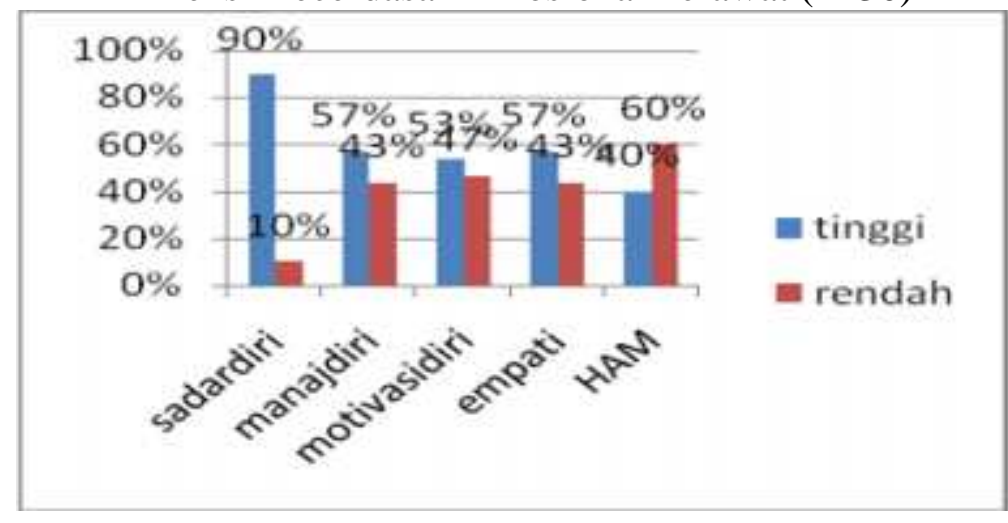

Diagram 3.

Distribusi Gaya Manajemen Konflik Perawat $(n=30)$

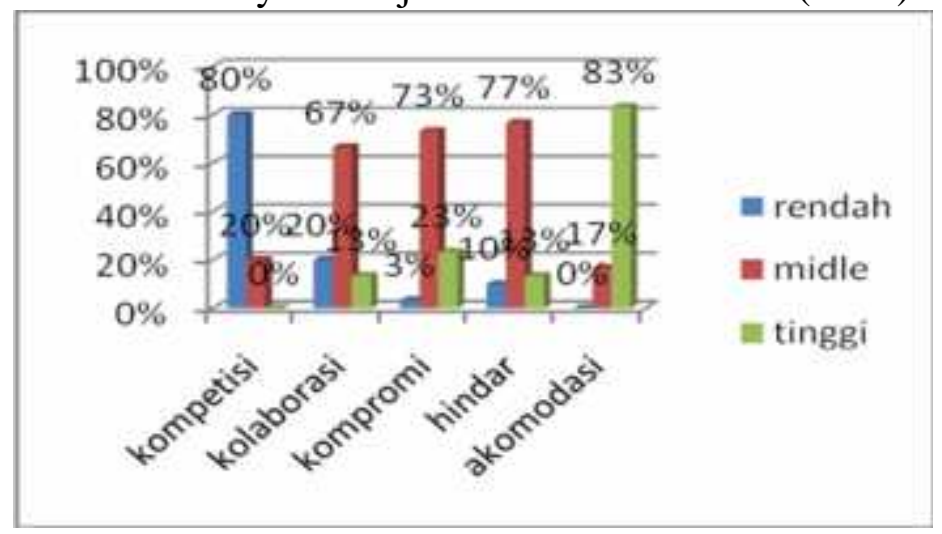




\section{Hasil Uji Hipotesis}

Berikut ini akan disampaikan hasil uji hipotesis dari kecerdasan emosional dengan gaya manajemen konflik :

Tabel 4.

Hasil Uji Data Demografi dengan Kecerdasan Emosional $(\mathrm{n}=30)$

\begin{tabular}{|c|c|c|c|c|c|}
\hline \multirow[b]{2}{*}{$\begin{array}{c}\text { Status } \\
\text { demografi }\end{array}$} & \multicolumn{5}{|c|}{ Dimensi Kecerdasan Emosional $r(p)$} \\
\hline & $\begin{array}{c}\text { Kesadaran } \\
\text { diri }\end{array}$ & $\begin{array}{l}\text { Manajemen } \\
\text { diri }\end{array}$ & Motivasi diri & Empati & $\begin{array}{l}\text { Kemampuan } \\
\text { membina hubungan } \\
\text { interpersonal }\end{array}$ \\
\hline Usia & $0,212(0,26)$ & $0,342(0,064)$ & $-0,088(0,64)$ & $-0,011(0,95)$ & $0,198(0,295)$ \\
\hline Jenis & - & $0,102(0,59)$ & $0,147(0,437)$ & $0,276(0,14)$ & $0,184(0,331)$ \\
\hline kelamin & $0,184(0,331)$ & & & & \\
\hline $\begin{array}{l}\text { Status } \\
\text { pernikahan }\end{array}$ & $0,05(0,792)$ & $0,112(0,556)$ & $-0,443(0,14)$ & $-0,075(0,69)$ & $-0,05(0,792)$ \\
\hline $\begin{array}{l}\text { Tingkat } \\
\text { pendidikan }\end{array}$ & $\begin{array}{c}- \\
0,078(0,684)\end{array}$ & $-0,36(0,049)$ & $-0,11(0,56)$ & $0,116(0,54)$ & $0,078(0,68)$ \\
\hline $\begin{array}{l}\text { Lama } \\
\text { bekerja }\end{array}$ & $0,131(0,49)$ & $0,473(0,008)$ & $\begin{array}{c}- \\
0,105(0,581)\end{array}$ & $0,049(0,797)$ & $0,196(0,299)$ \\
\hline
\end{tabular}

Tabel 5.

Hasil Uji Data Demografi dengan Kecerdasan Emosional ( $\mathrm{n}=30)$

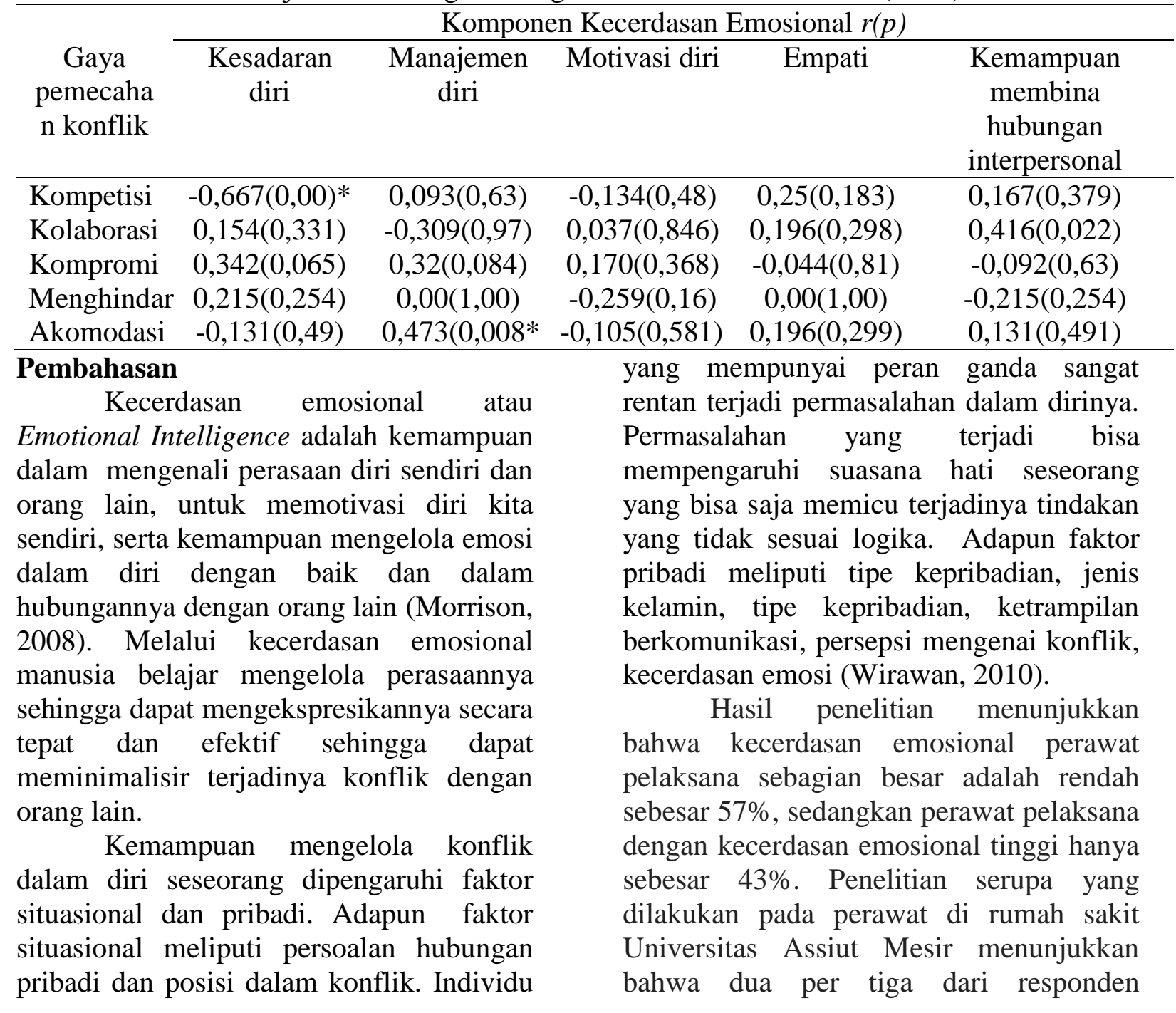


penelitiannya mempunyai level kecerdasan emosional dalam tingkat menengah (mild). Kondisi tersebut dimungkinkan karena pengalaman bekerja yang masih sedikit sehingga kurang terpapar dalam menyelesaikan masalah (Mohamed \& Yousef, 2014). Kondisi serupa ditemukan pada data demografi perawat di Rumah Sakit RSM Ahmad Dahlan, bahwa lama bekerja perawat rata-rata adalah 3-4 tahun dan usia 26,37 tahun.

Kecerdasan emosi tidak bisa diciptakan dalam waktu singkat, namun terbentuk oleh proses serta perjalanan hidup seseorang. Kecerdasan emosional sangat dipengaruhi oleh kondisi fisik serta psikis. Kondisi fisik terkait kesehatan otak secara anatomis dan fisiologis. Jika otak mengalami kelainan anatomis akan berpengaruh dalam kinerjanya sehingga perubahan transmitter di neuron. Sistem limbic sering disebut sebagai emosi otak yang letaknya jauh didalam hemisfer otak besar dan terutama bertanggung jawab atas pengaturan emosi dan implus. Sistem limbik dipercaya sebagai tempat berlangsungnya proses pembelajaran emosi dan tempat disimpannya emosi. Selain itu ada amygdala yang dipandang sebagai pusat pengendalian emosi pada otak (Goleman \& Nunes, 2003).

Selain fisik, factor non fisik juga ikut mempengaruhi perkembangan emosi seseorang, yaitu factor psikis yang terbentuk melalui perjalanan dalam kehidupan keluarga dan lingkungan. Factor eksternal tersebut akan menempa diri seseorang sehingga seseorang akan belajar dengan mengembangkan koping dalam dirinya(Ghorbani \& Razavi, 2011).

Hasil penelitian menunjukkan bahwa dimensi sadar diri merupakan dimensi tertinggi dari kecerdasan emosional responden dengan prosentase sebesar $90 \%$. Hal tersebut menunjukkan penerimaan perawat akan kekurangan dan kelebihan dirinya. Dimensi ini akan membantu perawat dalam memilih gaya manajemen konflik yang nantinya akan digunakan sehingga tidak menambah konflik baru. Hal tersebut senada dengan hasil penelitian Basogul dan Ozgur (2016) dalam peran kecerdasan emosional terhadap strategi manajemen konflik perawat bahwa dimensi sadar diri akan meningkatkan kemampuan perawat dalam manajemn konflik (Basogul \& Ozgur, 2016). Kemampuan mengenali diri sendiri dengan baik akan membantu perawat dalam memberikan pelayanan yang terbaik kepada pasien yang pada akhirnya akan meningkatkan kualitas pelayanan rumah sakit (Ezzatabadi et al., 2012). Namun begitu yang menarik dari hasil penelitian diperoleh bahwa dari sekian banyak dimensi kecerdasan emosional mempunyai nilai yang tinggi akan tetapi dimensi membina hubungan dengan orang lain memiliki nilai yang rendah. Hal tersebut bisa saja disebabkan karena kemampuan komunikasi dengan kolega dalam sebuah organisasi mengalami kegagalan.

Kemampuan membina hubungan dengan orang lain (Relationship Management) merupakan kemampuan menangani emosi dengan baik ketika berhubungan baik dengan orang lain serta menciptakan hubungan yang harmoni. Kemampuan dalam membina hubungan merupakan ketrampilan yang dapat menunjang popularitas dan leadership (Akanji, Ajonbadi, \& Mojeed-sanni, 2018). Kegagalan seorang perawat dalam membina hubungan dengan orang lain bisa disebabkan oleh gagalnya komunikasi dalam organisasi (Brusko, 2010). Komunikasi dalam organisasi dipengaruhi oleh struktur organisasi dalam suatu perusahaan, perbedaan status yang mencolok, rendahnya rasa percaya diri dalam diri personel, iklim komunikasi yang tertutup, serta kompleksnya pesan yang muncul (Omisore \& Abiodun, 2014).

Pemilihan gaya akomodasi yang sangat tinggi oleh responden sebesar $80 \%$. Penelitian sebelumnya menunjukkan gaya menghindar, kompetisi, dan akomodasi banyak dipilih oleh perawat dalam menyelesaikan konflik (Basogul \& Ozgur, 2016). Gaya akomodasi juga menjadi 
pilihan peraatdalam menghadapi konflik di tempat kerja diikuti oleh gaya kompromi, mewajibkan, dominasi, dan menghindar (Hamdan, Norrie, \& Anthony, 2014). Orang yang terlalu sering menggunakan gaya akomodatif menunjukkan kurangnya keinginan untuk berubah dan biasanya menunjukkan kecemasan akan ketidakpastian masa depan. Prinsip mendasar gaya akomodasi adalah menjaga semuanya tetap sama. Bila gaya ini terlalu sering digunakan, perasaan tertekan dan dendamdikhawatirkan akan muncul. Namun bila gaya akomodatif kurang dimanfaatkan, seseorang mungkin menunjukkan sikap apatis terhadap kepentingan orang lain (Kilmann \& Thomas, 2014).

Tingkat pendidikan mempunyai korelasi negative dengan dimensi manajemen diri, dengan nilai $r$ 0,36, artinya semakin tinggi tingkat pendidikan responden semakin kecil kemampuan dalam mengatur emosi diri. Terkait hasil ini belum ada kajian penelitian yang menyampaikan hal tersebut, namun ada penelitian yang menyebutkan berbeda bahwa terdapat korelasi positif antara tingkat pendidikan dengan kecerdasan emosi. Adapun pendidikan yang dimaksud dalam penelitian adalah tingkat strata 1 atau magister. Kajian pustaka menyatakan bahwa pendidikan merupakan factor eksternal yang dapat menjadi sarana mengembangkan kecedasan emosi seseorang karena dengan pendidikan (Agustian, 2007).

$$
\text { Lama bekerja secara statistik }
$$
mempunyai korelasi positif dengan dimensi manajemen diri responden meskipun dengan nilai korelasi rendah. Lama bekerja berdampak pada pengalaman yang diperoleh. Semakin lama bekerja, seseorang akan mendapatkan banyak pengetahuan baru maupun masalah baru (Mohamed \& Yousef, 2014). Temuan menunjukkan bahwa rata-rata perawat bekerja tidak lebih dari 5 tahun karena rumah sakit tempat penelitian merupakan rumah sakit dalam tahap pengembangan.
Hasil penelitian menunjukkan terdapat korelasi negative antara dimensi kesadaran diri (self awareness) dengan gaya kompetisi dengan nilai korelasi kuat $(\mathrm{r}=0,667)$. Bisa disimpulkan bahwa semakin tinggi kemampuan kesadaran diri seseorang akan semakin kecil kemungkinan menggunakan gaya kompetisi. Hal berbeda dalam penelitian sejenis bahwa terdapat korelasi positif antara self awareness dengan gaya kolaborasi, akomodasi, kompetisi, dan kompromi (Basogul \& Ozgur, 2016). Penelitian lain menyebutkan dimensi kesadaran diri dan empati mempunyai korelasi positif dengan gaya kolaborasi dan kompetisi (Jordan \& Throth, 2004). Dimensi manajemen diri secara statistic mempunyai korelasi positif dengan gaya akomodasi dengan nilai $r$ cukup. Hasil yang sama ditunjukkan penelitian lain namun dengan nilai $r$ yang sangat lemah (Basogul \& Ozgur, 2016).

\section{Simpulan dan Saran}

Responden didominasi perempuan $(76,7 \%)$ dengan status telah menikah $(73,3 \%)$ dan tingkat pendidikan sebagian besar adalah strata $1(66,7 \%)$. Gaya akomodasi menjadi pilihan terbanyak dari responden sebesar $83 \%$. Hasil analisis menunjukkan terdapat korelasi negative antara dimensi kesadaran diri dengan gaya kompromi dan korelasi positif antara dimensi manajemen diri dengan gaya kompetisi. Status lama bekerja responden mempunyai korelasi positif dengan kemampuan manajemen diri perawat.

Pimpinan perawat dan perawat pelaksana harus menguasai skill dalam manajemen konflik tentunya dengan menggunakan berbagai macam gaya. Selain itu budaya kerja yang konstruktif dalam mendorong kecerdasan emosional juga harus menjadi kebijakan manajer rumah sakit. Bagi peneliti selanjutnya diharapkan dapat melakukan uji kecerdasan emosional terhadap penggunaan gaya konflik dengan responden yang lebih banyak. 


\section{Daftar Pustaka}

Agustian, A.G. (2007). Rahasia Sukses Membangun Kecerdasan Emosi dan Spiritual ESQ: Emotional Spiritual Quotient Berdasarkan 6 Rukun Iman dan 5 Rukun Islam. Jakarta: Arga Publishing

Akanji, B., Ajonbadi, H., \& Mojeed-sanni, B. (2018). Impact of leadership styles on employee engagement and conflict management practices in Nigerian universities Research question. Educational Research, 28(4), 830-849.

Basogul, C., \& Ozgur, G. (2016). Role of Emotional Intelligence in Conflict Management Strategies of Nurses. Asian Nursing Research, 10, 228233.

https://doi.org/10.1016/j.anr.2016.07. 002

Brusko, L. (2010). Organized Chaos: A Survey of Conflict Management Strategies, Gender Roles, and Status in an Organizational Setting. $U W-L$ Journal of Undergraduate Research, XIII, 1-11.

Ezzatabadi, M. R., Bahrami, M. A., Hadizadeh, F., Arab, M., Nasiri, S., Amiresmaili, M., \& Ahmadi, G. (2012). Nurses , Emotional Intelligence Impact on the Quality of Hospital Services, 14(12), 12-17. https://doi.org/10.5812/ircmj.926

Ghorbani, M., \& Razavi, N. H. (2011). The Study of the Relationship Between Organizational Culture and Conflict Management, 10(6), 711-717.

Goleman, D., \& Nunes, R. (2003). Working With Emotional Intelligence, 1-7.

Hamdan, Z. Al, Norrie, P., \& Anthony, D. (2014). Conflict management styles used by nurses in Jordan.
Jones, R. A. P. (2007). Nursing Leadership and Management: Theoris, Processes and Practice. Philadhelpia: F.A. Davis Company.

Jordan, P. J., \& Throth, A. C. (2004). Managing Emotions During Team Problem Solving: Emotional Intelligence and Conflict Resolution. Human Performance, 17(2), 195218.

Kilmann, R. H., \& Thomas, K. W. (2014). Developing a Forced-Choice Measure of Conflict-Handling Behavior: The " MODE " Instrument. Educational and Psychological Measurement, 37(2), 309-325.

https://doi.org/10.1177/00131644770 3700204

Mohamed, F. R., \& Yousef, H. R. (2014). Emotional Intelligence and Conflict Management Styles among Nurse Managers at Assiut University Hospitals, 5(5), 160-165.

Morrison, J. (2008). The relationship between emotional intelligence competencies and preferred conflict. Journal of Nursing Management, 16(8), 974-983.

Obied, H. K., \& Ahmed, S. E. S. (2016). Effect of Utilizing Conflict Management Strategies for ICU Nurses on Patient Care, 5(2), 39-46. https://doi.org/10.9790/19590502053946

Omisore, B. O., \& Abiodun, A. R. (2014). Organizational Conflicts: Causes , Effects and Remedies, 3(6), 118137.

Rahim, M. A. (2017). Managing Conflict in Organization (4th ed.). New York: Taylor \& francis. https://doi.org/https://doi.org/10.432 4/9780203786482 
Schaubhut, N. (2007). Technical Brief for the THOMAS-KILMANN

CONFLICT MODE INSTRUMENT Description of the Updated Normative Sample and Implications for Use. USA: CPP Research Departmen.

Shapiro, G. J. (2014). Identifying the Factors That Influence Conflict Management Behavior of Human Resource Professionals in the Workplace: An Analysis of the Relationship Between Personality and Conflict Management Behavior. Nova Southeastern University. Retrieved from https://nsuworks.nova.edu/cgi/viewc ontent.cgi? article $=1025 \&$ context $=$ shs s_dcar_etd

Wirawan. (2010). Konflik dan Manajemen Konflik: Teori, Aplikasi \& Penelitian. Jakarta: Salemba Humanika.

Yamani, N., Shahabi, M., \& Haghani, F. (2014). The relationship between emotional intelligence and job stress in the faculty of medicine in Isfahan University of Medical Sciences. Journal of Advances in Medical Education \& Profesionalism, 2(1), 20-26. 